\title{
Hét vulkáni kőzeten kialakult talajszelvény morfológiai és diagnosztikai jellemzői a hazai genetikai talajosztályozás és a WRB (World Reference Base for Soil Resources, 1998) szerint
}

\author{
${ }^{1}$ FEHÉR OLGA, ${ }^{1}$ FÜLEKY GYÖRGY, ${ }^{2}$ MADARÁSZ BALÁZS és \\ ${ }^{2}$ KERTÉSZ ÁDÁM \\ ${ }^{1}$ Szent István Egyetem Talajtan és Agrokémia Tanszék, Gödöllő és \\ ${ }^{2}$ MTA Földrajztudományi Kutatóintézet, Budapest
}

\begin{abstract}
Bevezetés
A Kárpát-medence neogén-pleisztocén vulkáni képződményeinek tanulmányozása a hazai földtani és felszínalaktani kutatásokban fontos szerepet játszott, mivel a kárpáti vulkáni koszorú 1920-ig teljes egészében Magyarország területére esett (SZÉKELY, 1997). Az Osztrák-Magyar Monarchia gazdasági érdekei jól tükröződnek az első talajismereti felvételezésekben és monográfia jellegü munkákban, melyek a gabona- és szőlőtermesztés, illetve fakitermelés kulcsfontosságú területeiről készültek (SZABÓ \& MOLNÁR, 1867; FEKETE, 1891). Így nagyon valószínü, hogy a vulkáni talajokkal foglalkozó részletes talajtani ismertetés Tokaj-Hegyaljáról készült elöször Európában. Későbbi publikációkban a vulkáni talajok szinonimként szerepelnek a szőlőtalajokkal (TREITZ, 1905; STEFANOVITS, 1956; NAGYMAROSY, 2004). A hazai irodalomban a jelenkori és eltemetett talajokra vonatkozó, genetikus szemléletet tükrözö kutatások egy-egy vulkáni földrajzi egységhez, illetve speciális témakörhöz kötötten jelennek meg. Mikromorfológiai megfigyelések csak korlátozott számban készültek (RÓZSAVÖLGYI \& STEFANOVITS, 1960; STEFANOVITS, 1971; SzENDREI, 2001). A vulkáni kőzeteken képződött talajok átfogó genetikus vizsgálatát és a bennük lejátszódó folyamatok megválaszolását Kárpát-Pannon térség szinten STEFANOVITS $(1951,1956,1971)$ kutatásai fémjelzik.

2001-ben a COST 622 munkacsoport megkeresésére lehetőségünk nyílt az európai vulkáni területek talajerőforrásait feltérképező és vizsgáló kutatásban részt venni. Az együttmüködés keretében munkánk egyik fő célkitüzése volt megvizsgálni, hogy a vulkanikus területeken (kőzeteken) megtalálható hazai talajtípusok a World Reference Base for Soil Resources (WRB, 1998) szerint egymástól elváló módon kerülnek-e besorolásra. Fő módszernek a részletes makro- és mikromorfológiai megfigyeléseket tekintettük, melyeket standard laboratóriumi módszerekkel egészítettünk ki. Jelen dolgozat a 2001-2004 között folyt kutatómunka Magyarországra vonatkozó föbb vizsgálati eredményeit összegzi.
\end{abstract}

Postai cím: FEHÉR OLGA, Szent István Egyetem Talajtan és Agrokémia Tanszék, 2103 Gödöllő, Páter K. u. 1.E-mail: olenyka@spike.fa.gau.hu 
FEHÉR et al.

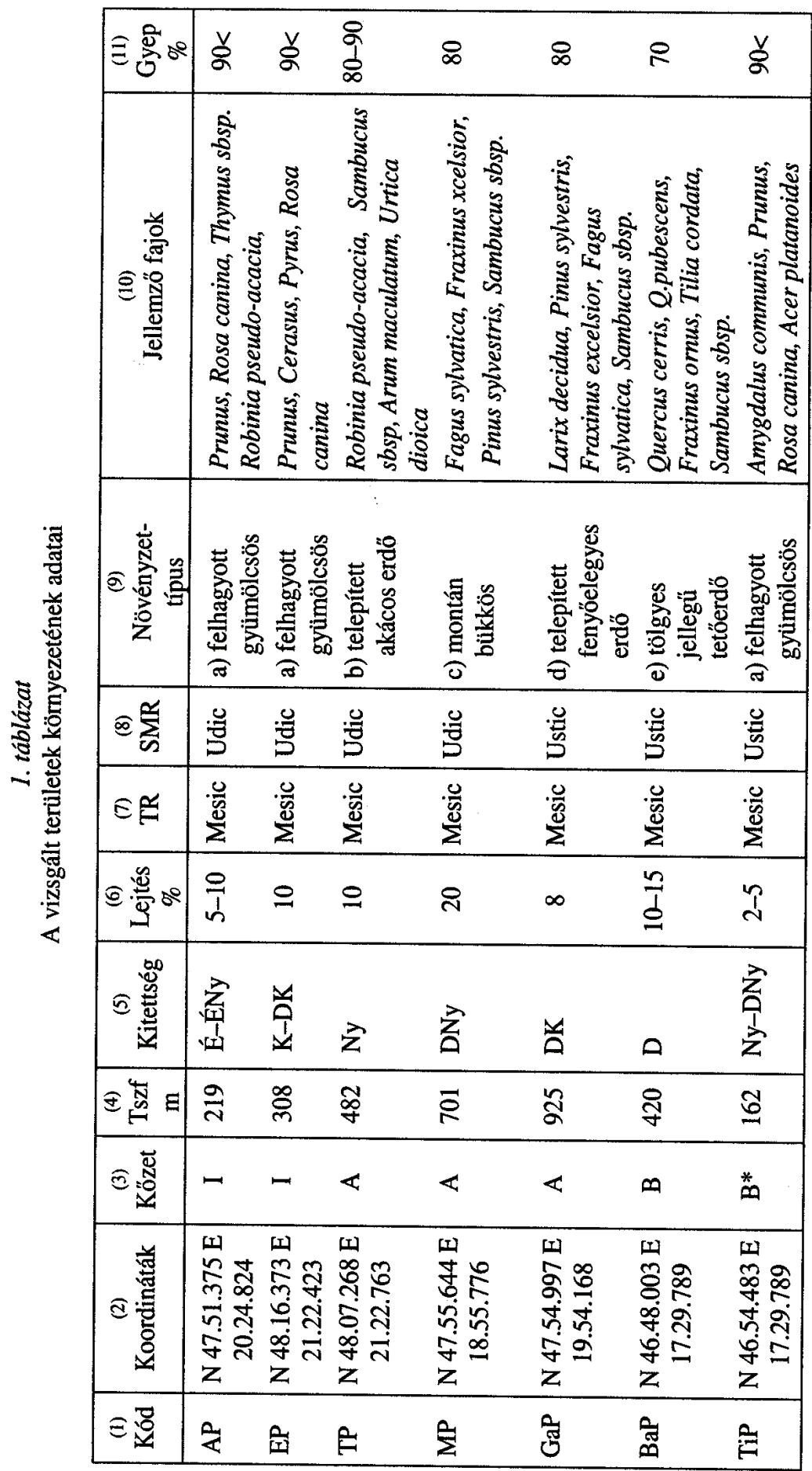

过

容密

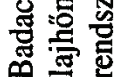

空

$\cong$

影零

สํำ

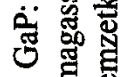

惫焉

空密言

运总总

운

音芯岕

它昰

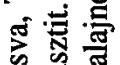

흥 항

总密

空言

昰

鱼

严潈

这悬

di

守

总

产芒的

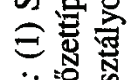

풍

纤

今㵧 
A vizsgált területek környezetének általános jellemzése

A vizsgált területek megválasztásának kiindulási alapja a miocén-pliocén időszakban végbement belső-kárpáti mészalkáli (SZAKÁCS \& KARÁTSON, 1999) és a medencebelseji alkálibazalt (HARANGI, 1999) vulkánosság által felszínre került termékek előfordulása volt. Így a feltételezett talajképződést szolgáló kiömlési magmás kőzetek (STEFANOVITS et al., 1999) jellege alapján dolgozatunkban hét reprezentatív talajszelvény vizsgálati eredményeit mutatjuk be (1. táblázat).

A ,savanyú" vulkanikus területek talajszelvényeit, az andornaktályi (AP) és a tolcsvai (EP) szelvények képviselik, melyek a riolitos-riodácitos ignimbrittakarón (SZAKÁCS \& KARÁTSON 1999) alakultak ki. Az intermedier vulkánosság andezit területeiről: a magas-taxi (MP), a galyatetői (GaP) és a Tokaj-hegyi (TP) szelvényeket választottuk. A medencebelseji alkálibazalt vulkánosság (HARANGI, 1999) által felszínre hozott kőzeteken kialakult talajokat a badacsonyi (BaP) és a tihanyi szelvények (TiP) képviselik. A vizsgált területek talajainak jelenkori morfológiai és kémiai tulajdonságait, illetve a paleo talajképződés reliktum bélyegeinek átöröklését döntően befolyásolja a vulkáni kőzetek keletkezése óta lezajlott felszínfejlődés. Ez röviden összefoglalva: stabilitási fázisok (talajképződésnek kedvező időszakok) és a felszínpusztulást előidéző folyamatok (geológiai, illetve ember által indukált eróziós és szedimentációs folyamatok) váltakozásából tevődik össze.

A vizsgált szelvények, nemzetközi talajosztályozási rendszerek szerinti, talajhőmérsékleti (TR) típusa mesic, talajnedvesség-forgalmi típusai (SMR) ustic és udic között oszlanak meg (1. táblázat). A dolgozatunkban szereplö területek többségére éves szinten a talajban víztöbblet jellemző, mely kilúgzó vízháztartást eredményez.

Az ember által előidézett bolygatás, zavarás hatásának egyértelmü kizárása érdekében egy korábbi munkánkban (FEHÉR \& MADARÁSZ, 2004) részletes elemzést végeztünk a földhasználat változások nyomon követésére. Így olyan területek kerültek kiválasztásra, melyeknél természetes vagy természeteshez közeli állapottal számolhatunk és ahol a sürü növényborításnak köszönhetően nincs erózió. Megfigyeléseink alapján megállapítottuk, hogy a magas-taxi és a galyatetői szelvények esetében a morfológiai sajátosságok további értelmezéséből az ember által előidézett eróziós és szedimentációs folyamatok egyértelműen kizárhatók, míg a többi szelvénynél a talajképződés csak az elmúlt 100 évben tekinthető embertől függetlennek.

\section{Anyag és módszer}

A terepbejárások során a szelvénykijelöléseknél próbafúrásokat végeztünk Eijkelkamp-kombinált fúróval. A talajszelvények morfológiai leírása a FAO (1990) útmutató szerint történt, mely a közben futó COST 622 projekt által elöírt szabvány volt. A genetikai szintek jelölésénél STEFANOVITS et al. (1999) által publikált jelöléseket alkalmaztuk. Terepi vizsgálatainknál különös figyelmet fordítottunk: a humuszformák (mor, moder, mull) megítélésére; a gyökérfejlődést akadályozó tényezőkre; a biológiai aktivitásra (állatjáratok); a talajszerkezetre; a kövességre (kőzet 
FEHÉR et al.

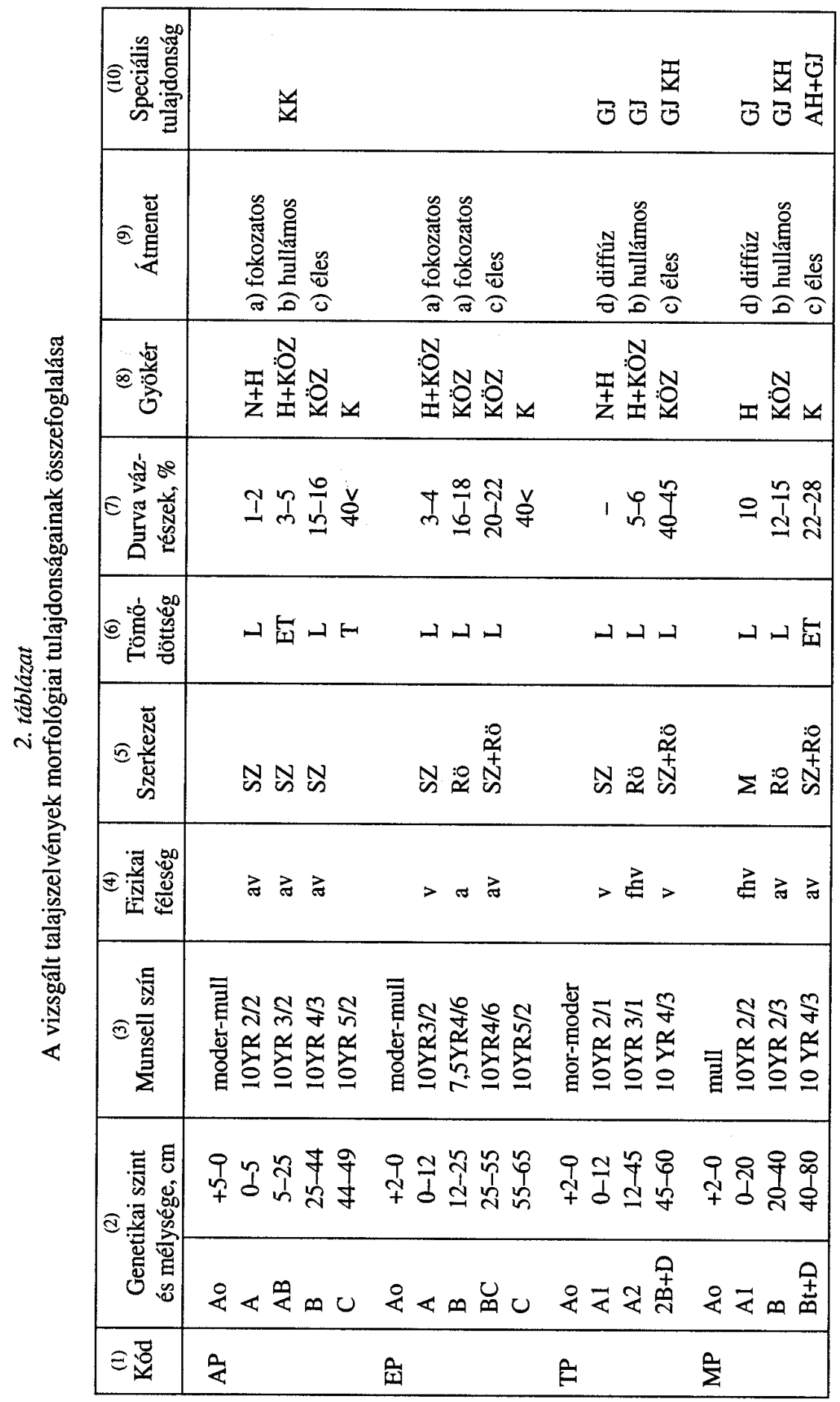




\begin{tabular}{|c|c|c|c|}
\hline 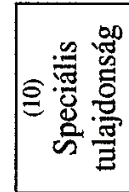 & 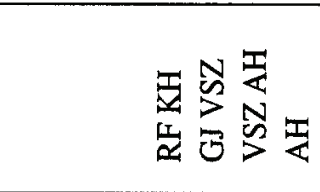 & ○ & \\
\hline ف思 & 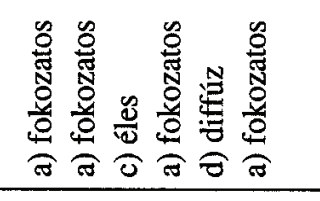 & 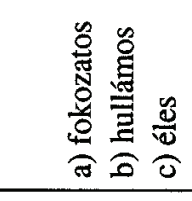 & 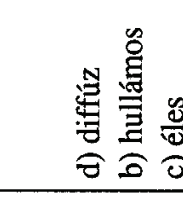 \\
\hline 产咅 & z & 坣: & 索谓、 \\
\hline 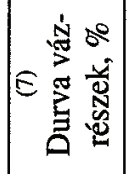 & 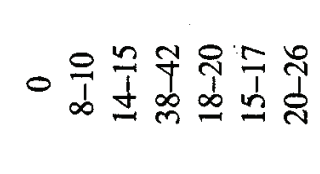 & $00 \stackrel{v}{n}$ & 인 \\
\hline 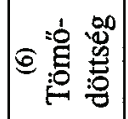 & 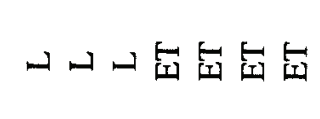 & دـ & 它㫐 \\
\hline 苞 & 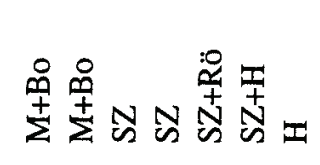 & 心: & 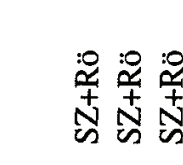 \\
\hline 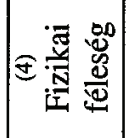 & 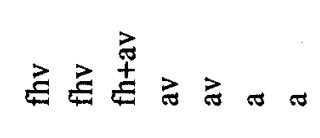 & নे $\vec{~}$ & 己 \\
\hline 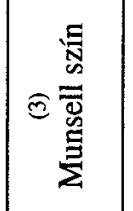 & 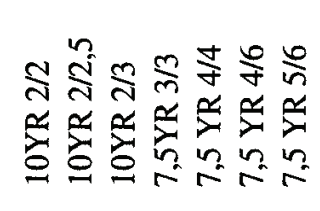 & 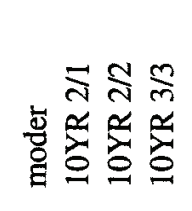 & 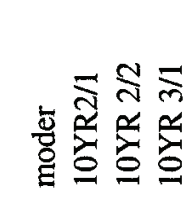 \\
\hline \multirow{2}{*}{ 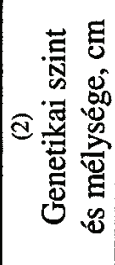 } & 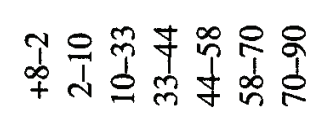 & 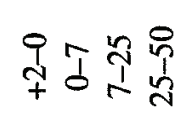 & 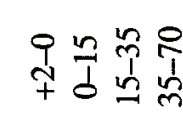 \\
\hline & 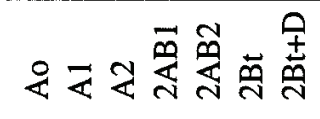 & 是元妥旪 & 最云妥采 \\
\hline$\Xi_{\mathscr{4}}^{\vec{B}}$ & స్ & 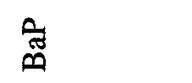 & $\hat{\sharp}$ \\
\hline
\end{tabular}

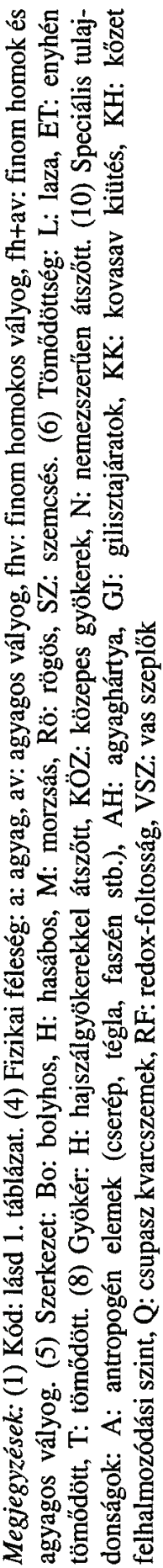


törmelék mennyisége, formája, szelvénybeli elhelyezkedése); a kiválások, bevonatok előfordulása; a szelvény folytonosságára (,idegen” anyagok, üledékráhordás); a talajtest kapcsolatára a vulkanikus kőzettel. Morfológiai bélyegeiben a galyatetői szelvény bizonyult a legösszetettebbnek; így a szelvényt kialakító folyamatok megértése érdekében ismert orientációjú bolygatatlan mintákat vettünk, melyekböl $60 \times 90 \mathrm{~mm}$ vékonycsiszolatok készültek. A mikroszkópos megfigyeléseket Zeiss Axioplan 2 Universal polarizációs mikroszkópon végeztük. A vékonycsiszolatok leírásánál STOOPS (2003) fogalmait és szakkifejezéseit alkalmaztuk.

Laboratóriumi vizsgálatokhoz bolygatott átlag $(\sim 1,5-2 \mathrm{~kg})$ és bolygatatlan ismert térfogatú (szintenként 3 ismétlésben) és orientációjú mintákat vettünk. A térfogattömeget $(\rho)$ bolygatatlan ismert térfogatú mintákon szárítószekrényes eljárással határoztuk meg. Száraz szitálással elválasztott földes részből: talajoldat kémhatását $\left(\mathrm{pH}_{H 2 O}, \mathrm{pH} \mathrm{H}_{K C}\right)$; szerves-szén-tartalmat $(O C \%)$ (Tyurin-féle); felvehető foszfortartalmat $(P)$ (AL- és Olsen-módszer), foszfátadszorpciót $\left(P_{\text {ret }} \%\right)$ káliumdihidrogén-foszfát $\mathrm{pH}=4,6$ oldatból határoztuk meg (BUZÁs et al., 1988, 1993; BLAKEMORE et al., 1987). A kationcsere kapacitást (CEC) ammónium-acetátos $(\mathrm{pH}=7)$ módszerrel csak három szelvénynél volt módunk meghatározni (BLAKEMORE et al., 1987). A bázistelítettséget $(B \%)$ a többi szelvénynél az $f\left(p H_{H 2 O}\right)=B \%$ összefüggésböl becsültük (WHITE, 1997). A karbonáttartalmat sósavas lecseppentéssel ellenőriztük. A talajképződés során keletkezett pedogén vagy az angolszász irodalomban gyakran ,szabad” oxidokként jelölt $F e_{d}$ és $A l_{d}$ komponenseket (Mehra \& Jackson módszer) nátrium-ditionitos (pH 7,3) oldattal vontuk ki. Az amorf, illetve kismértékben kristályosodott oxidok (pl. ferrihidrit) komponenseit $\left(A l_{o}, F e_{o}\right.$ és $\left.S i_{o}\right)$ ammónium-oxaláttal $(\mathrm{pH} 3)$ vittük oldatba. A talaj szerves fázisához kötött $A l_{p}$ - és $F e_{p}$-tartalmat nátrium-pirofoszfátos szelektív extrakcióból keletkezett oldatból becsültük. A szelekciós oldási módszerekkel nyert Fe-, Al- és Sitartalmat atomabszorpciós spektrofotometriával (AAS) határoztuk meg. A mechanikai összetétel meghatározását pipettás eljárással végeztük (BUZÁs et al., 1993). Egyes esetekben (4. táblázat: APH3, EPH3, TPH3, MPH2-3, GaPH3-4, BaPH2, TiPH3) a laboratóriumi mechanikai összetétel meghatározás eredményei, többszörös ismétlések után is, messze eltértek a terepen tapasztalt fizikai féleségtől. Ezekben az esetekben, nedves szitálással ( $50 \mu \mathrm{m}$ szita) nyert homokminták morfológiáját vizsgáltuk pásztázó-elektron mikroszkóp (JEOL JSM 6400, Genti Egyetem) segítségével. A talajok besorolását a WRB (1998) kiadványa szerint végeztük.

\section{A vizsgálati eredmények és megvitatásuk}

\section{Szelvénymorfológiai megfigyelések}

A szelvényleírások eredményeit a 2. táblázat összegzi. A „savanyú” vulkanikus terület szelvényeinek (AP, EP) morfológiájára jellemző volt a zavartalan in situ fejlődés, mivel a talajtest és a talajképző kőzet közötti átmenet folyamatos, jól észlelhető mállásfronttal. A vizsgált szelvények mélysége átlagosan $40-50 \mathrm{~cm}$ volt, ugyanakkor az effektív gyökérzóna mélysége jóval meghaladta az 1,5-2 m-t, így a 
gyökérnövekedést az ignimbritek nem akadályozták. A talajszelvény szintekre tagolódására jellemző a szerves anyagban gazdag, barnásfekete színü, jól fejlett aprószemcsés szerkezetü és igen aprókavicsos (2-4\%), humuszos A-szint. Ezt a szerkezetében és színében hasonló, de jóval kövesebb (16-18\%), B-szint követi. Az andornaktályi szelvényben fehéresen impregnált, de morzsolásra széteső szerkezeti elemeket figyeltünk meg, melyek sósavval lecseppentve nem pezsegtek. Ezek nagy valószínüséggel kovasav kiütések.

A dunántúli bazaltvulkános területek talajainál (BaP, TiP) szembeötlő volt a talajtest és az ágyazati közet közötti éles határvonal, mely a múltban végbement drasztikus erózióra utalhat. Az előzetes szelvény-kijelöléseknél igyekeztünk bolygatatlan szelvényt feltárni, ugyanakkor a környék múltját ismerve feltételezhető volt az emberi hatás. Így véleményünk szerint a bazaltos alapkőzeten feltárt szelvények mélysége igazából a másodlagosan áthalmozott üledék vastagságától függ. Az áthalmozás ideje óta a talajképződésre utaló bélyegek: színben (sötétbarna-sötét vörösesbarna) és szerkezetben (durva aprószemcsés), humuszban gazdag (mull típusú) jól elkülöníthető A-szint, mely hullámosan megy át a színben halványabb, szövetében enyhén agyagosabb B-szintbe, melyet rosszul osztályozott, különböző méretü és formájú kőzet-darabok jellemeztek.

Az intermedier vulkánosság piroxén-andeziten található középhegységi szelvények (TP, MP, GaP) humusztípusa savanyú mull; szerkezetük erősen fejlett aprószemcsés vagy morzsás, szemmel jól látható biopórusokkal. A savanyú mull humusztakaró képződése az intenzív mállás folyamán felszabaduló vasoxidok és hidroxidok (5. táblázat) jelenlétére, illetve az igen nagyfokú biológiai aktivitásra vezethető vissza (DUCHAUFOUR, 1982).

Galyatetőnél a genetikus szintek jól elkülönülő színeinek köszönhetően a gilisztajáratok 44-50 cm mélységig jól láthatóak, ez nyárvégi, kora őszi talajkiszáradásra enged következtetni. Mindhárom észak-középhegységi talajszelvény esetében szembetűnő volt - MP esetében $20-40 \mathrm{~cm}, \mathrm{GaP} 33-44 \mathrm{~cm}$, míg a TP szelvényben 45-60 cm mélységben található - mállatlan kőzettörmelék felhalmozódási zóna, melyet homokos vályog szövetü, löszszerủ anyag fedett. Ez utóbbi képezi a jelenlegi talajtest szerves anyagban és finom gyökerekben igen gazdag humuszos Aszintjét. A közettörmelék felhalmozódási szint alatt egy színben elütő (élénk vörösesbarna), agyaghártyákban, vas szeplőkben és ujjnyomásra szétporladó, erősen mállott kőzetben gazdag genetikai szint található, melyet az MP és GaP szelvények esetében eltemetett felhalmozódási szintként ( $2 \mathrm{Bt}$ ) írtunk le. A feltalaj és az altalaj közötti különbségek különösen Galyatető esetében voltak feltủnőek, így ezt a szelvényt mikromorfológiailag is megvizsgáltuk.

\section{Mikromorfológiai sajátosságok}

A feltalaj és az altalaj mikromorfológiai sajátosságai több pontban igazolták a vizsgált szintek eltérő genetikai eredetét. A feltalaj porozitása igen magas, ami összhangban van az igen alacsony térfogattömeg értékekkel (3. és 4. táblázat).

A feltalajban a mikroszerkezet morzsás $(100-250 \mu \mathrm{m})$, ezzel szemben az altalajt egymástól jól elkülönülő tömött (pórusmentes) rögös, 2000-4000 $\mu \mathrm{m}$ nagyságú 
3. táblázat

A galyatetői szelvény mikromorfológiai tulajdonságainak összegzése

\begin{tabular}{|c|c|c|c|c|c|c|c|c|c|c|c|c|}
\hline \multicolumn{2}{|c|}{$\begin{array}{c}\text { (1) } \\
\text { Mikroszerkezet }\end{array}$} & \multicolumn{7}{|c|}{$\begin{array}{c}(4) \\
\text { Alapanyag }\end{array}$} & \multicolumn{4}{|c|}{$\begin{array}{c}\text { (5) } \\
\text { Talajképzödéshez } \\
\text { kötött termékek }\end{array}$} \\
\hline \multirow{2}{*}{$\begin{array}{l}\text { (2) } \\
\text { Alak }\end{array}$} & \multirow{2}{*}{$\begin{array}{c}(3) \\
\mathrm{P} \\
\% \\
\end{array}$} & \multirow{2}{*}{ Asz } & \multirow[t]{2}{*}{ Akt } & \multirow[t]{2}{*}{$\mathrm{b}$} & \multirow[t]{2}{*}{$\mathrm{V} / \mathrm{a}$} & \multirow[t]{2}{*}{ Vw } & DV & Q & \multirow[t]{2}{*}{$\mathrm{AH}$} & \multirow[t]{2}{*}{$\mathrm{E}$} & \multirow[t]{2}{*}{ I } & \multirow[t]{2}{*}{$\mathrm{N}$} \\
\hline & & & & & & & \multicolumn{2}{|c|}{$\%$} & & & & \\
\hline $\mathrm{m} / \mathrm{sz}$ & $70-80$ & $\begin{array}{l}\text { a) sötét- } \\
\text { barna }\end{array}$ & $\begin{array}{l}\text { d) pigmen- } \\
\text { tes }\end{array}$ & I & $\mathrm{P}$ & $\begin{array}{c}0 \\
++\end{array}$ & 30 & 25 & & +++ & & ++ \\
\hline rö & $45-50$ & $\begin{array}{l}\text { b) bézs és } \\
\text { barna }\end{array}$ & $\begin{array}{l}\text { e) hetero- } \\
\text { gén }\end{array}$ & A & $\mathrm{P}$ & ++ & 40 & 10 & +++ & + & ++ & ++ \\
\hline rö & $50-60$ & $\begin{array}{l}\text { c) vörö- } \\
\text { sesbarna }\end{array}$ & f) pelyhes & A & $\mathrm{P}$ & ++ & 50 & 0 & +++ & & & +++ \\
\hline
\end{tabular}

Megjegyzések: (2) m: morzsás, rö: rögös, sz: szemcsés. (3) P\%: porozitás. (4) Asz: alapanyag finomszövetének színe; Akt:- alapanyag finomszövetének kísérő tulajdonságai; b: az alapanyag kereszt polárok közötti jellege: I: izotróp, A: anizotróp; V/a: vázrész/alapanyag szövettípus: P: porfíros; Vw: durva vázrészek mállásának intenzitása; $\mathrm{DV}$ : durva vázrészek eloszlása \%; Q: kvarcszemcsék eloszlása, \%; (5) AH: agyaghártya, E: ürülék, I: póruskitöltések, N: vaskiválások

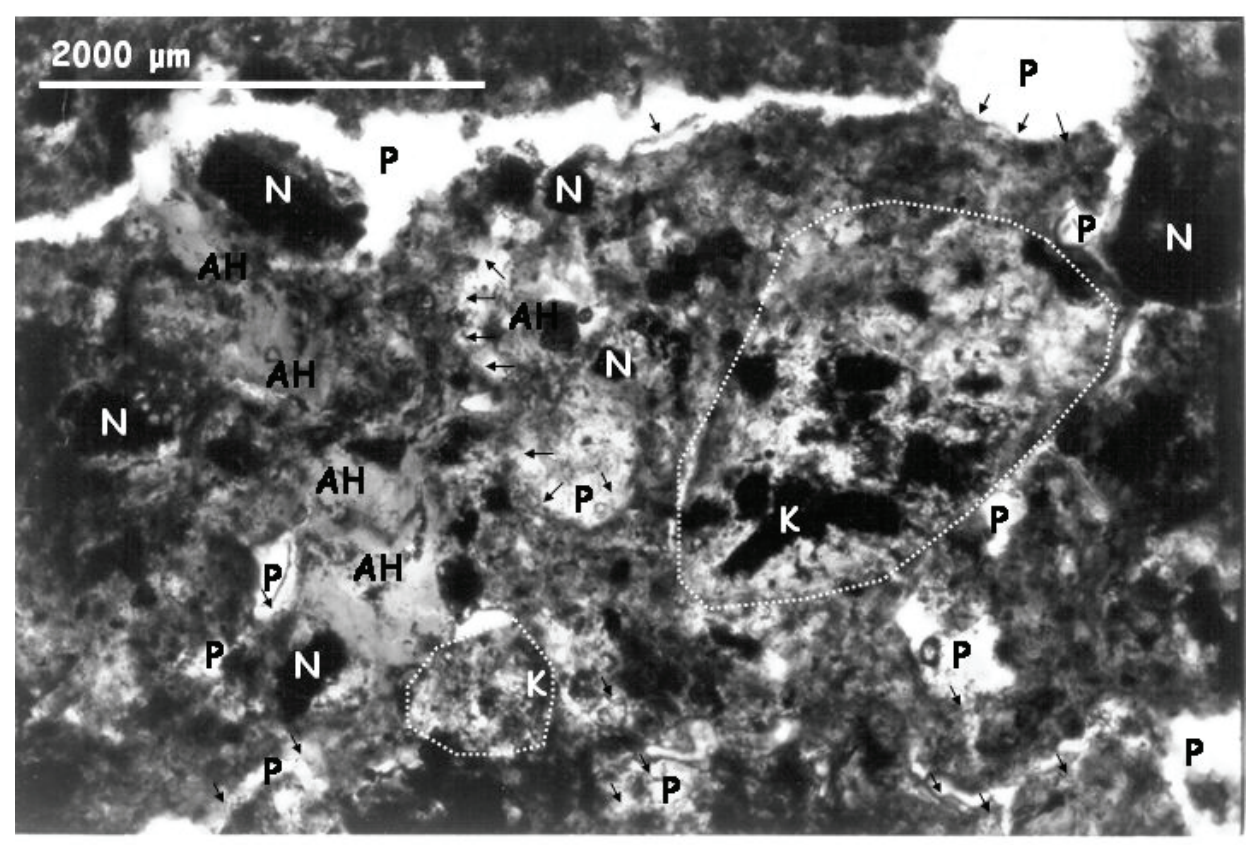

1. ábra

Geliflukciós heterogenitás. Galyatető, $42-55 \mathrm{~cm}$.

$\mathrm{AH} / \rightarrow$ : agyaghártya; K: kőzettörmelék; N: vaskiválás; P: pórus 
aggregátumok jellemzik. A feltalaj kolloidszövete sötétbarna színü, pöttyözött mátrixú, kereszt polárok között izotróp. Az altalajé vörösesbarna, pelyhes és a kereszt polárok között a kolloidszövet véletlenszerü narancsos foltosságot mutat, mely az alapszövetet felépítő 2:1 kristályrácsú agyagásványok jelenlétére utal. Közvetlenül a kőzettörmelék felhalmozódás alatti szintből vett vékonycsiszolatokban az aggregátumok heterogének, „folyósan” deformáltak (1. ábra). Az aggregátumok belsejében gyakran piros, éles szélü, típusos vaskiválásokat, szétdarabolt agyaghártyákat figyeltünk meg, mely bélyegek nagy valószínüséggel geliszoliflukciós transzportra engednek következtetni.

Jellegzetesnek tekinthető a szervetlen vázrészek közül a kvarcszemcsék eloszlása, melyeket gyakorlatilag csak a feltalajban figyeltünk meg. A kvarcszemcsék lekerekítettek és $100 \mu \mathrm{m}$-nál kisebbek, mely mérettartomány eolikus transzportra utal. Az altalajban kvarcszemcséket nem írtunk le, a szervetlen vázrészek zömét igen erősen mállott, vasas agyaggal impregnált durva homokszem nagyságú vulkáni kőzetdarabok jellemzik. Az altalajban gyakoriak a vaskiválások és szeparálódások. Az altalaj aggregátumainak falát vékony, poros agyag-iszapszerü bevonatok fedik, mely jelenkori agyagvándorlásra, belső kolluviációt (VAN VLIET LANOË, 1985) takarhat.

\section{Kémiai tulajdonságok}

A 4. és az 5. táblázatokban a laboratóriumi vizsgálatok eredményeit foglaltuk össze. Mindegyik szelvényre jellemző a magas szerves-szén-tartalom (1,22-9,46\%), mely a mélységgel ugyan csökken, mégis az altalajban is relatíve magas értékeket mutat, kivéve a „savanyú” és a magas középhegységi intermedier vulkánizmus területén megtalálható szelvényeket (4. táblázat).

Badacsony esetében a kiugróan magas szerves-szén, illetve a felvehető foszfor értékek, a BaPH2 és BaPH3 minták 50\%-ot meghaladó bázistelítettsége, továbbá a 3-nál sötétebb Munsell chroma-értékek (2. táblázat) emberi hatásra utalnak (WRB, 1998). Földhasználati térképeken jól nyomon követhető, hogy a terület csak a filoxéravészt követően erdősült vissza. Így a badacsonyi szelvény az $\mathrm{AB}+\mathrm{D}$-szintben talált cserépdarabok és a kémiai tulajdonságai alapján kultúrmaradvány talajnak tekinthetö.

A laboratóriumban meghatározott agyagtartalom (4. táblázat) messze elmaradt a terepen jelzett agyagosságtól. Különösen szembeötlő volt ez Galyatető, Magas-Tax, Tihany és Badacsony esetében. Pásztázó-elektronmikroszkópos vizsgálatokkal az APH3, EPH3, TPH3, MPH2-3, GaPH3-4, BaPH2 és TiPH3 szintekből vett mintákból sikerült kimutatni a diszpergálásnak ellenálló pszeudohomok-szemcséket (2. ábra). PEDE \& LANGOHR (1983) szerint a standard eljárással végzett mechanikai összetétel meghatározás során keletkező diszpergálási gondok három föbb okra vezethetök vissza: a talajt ért többszörös fagyás-olvadásra, szeszkvioxidok cementáló hatására, illetve a nagy arányú amorfkolloid-tartalomra.

A talajképződés során felszabaduló szabad szeszkvioxid-tartalom a ditionitoldható vasoxid-hidroxid $\left(\mathrm{Fe}_{\mathrm{d}}\right)$ adatok alapján becsülhetö (5. táblázat). Ez a vizsgált talajszelvények esetében Galyatetőnél a legmagasabb (3,17-4,05\%), mely nagy 
4. táblázat

A vizsgált hét vulkáni kőzeten kialakult talajszelvény laboratóriumi vizsgálati eredményei

\begin{tabular}{|c|c|c|c|c|c|c|c|c|c|c|}
\hline \multicolumn{2}{|c|}{$\begin{array}{c}\text { (1) } \\
\text { Minta }\end{array}$} & \multirow{2}{*}{$\begin{array}{c}(2) \\
\rho \\
\mathrm{g} / \mathrm{cm}^{3} \\
\end{array}$} & $\begin{array}{c}\text { (3) } \\
\text { Homok }\end{array}$ & $\begin{array}{l}\text { (4) } \\
\text { Por }\end{array}$ & $\begin{array}{c}(5) \\
\text { Agyag }\end{array}$ & $\begin{array}{l}\text { (6) } \\
\text { OC }\end{array}$ & \multirow{2}{*}{$\begin{array}{c}\text { (7) } \\
\mathrm{P} \\
\mathrm{mg} / \mathrm{kg} \\
\end{array}$} & \multicolumn{2}{|c|}{$\mathrm{pH}$} & \multirow{2}{*}{$\begin{array}{l}(8) \\
\mathrm{B} \\
\% \\
\end{array}$} \\
\hline kód & $\mathrm{cm}$ & & \multicolumn{4}{|c|}{$\%$} & & $\mathrm{H}_{2} \mathrm{O}$ & $\mathrm{KCl}$ & \\
\hline APH1 & $0-5$ & 1,09 & 33 & 50 & 18 & 1,09 & 18,85 & 6,29 & 5,72 & $>50$ \\
\hline APH2 & $5-25$ & 0,88 & 71 & 27 & 2 & 0,30 & 12,20 & 6,56 & 5,41 & $>50$ \\
\hline APH3 & $25-44$ & na & 81 & 18 & 0 & 0,12 & 9,94 & 6,65 & 5,20 & $>50$ \\
\hline EPH1 & $0-12$ & 0,98 & 50 & 35 & 14 & 2,60 & 75,86 & 6,49 & 5,67 & $>50$ \\
\hline ЕPH2 & $12-25$ & 0,98 & 42 & 34 & 24 & 0,56 & 24,64 & 6,20 & 5,04 & $>50$ \\
\hline EPH3 & $25-55$ & na & 60 & 31 & 9 & 0,37 & 20,17 & 6,37 & 5,06 & $>50$ \\
\hline TPH1 & $0-12$ & 0,72 & 7 & 68 & 25 & 4,54 & 12,7 & 5,14 & 4,57 & 59,4 \\
\hline ТPH2 & $12-45$ & 0,74 & 15 & 58 & 27 & 3,85 & 10,7 & 5,34 & 4,74 & 67,2 \\
\hline ТPH3 & $45-60$ & 1,20 & 61 & 36 & 3 & 1,35 & 16,7 & 5,80 & 5,07 & 67,9 \\
\hline MPH1 & $2-20$ & 1,03 & 19 & 60 & 21 & 1,22 & 2,76 & 5,43 & 4,22 & $<50$ \\
\hline MPH2 & $20-40$ & 1,07 & 20 & 69 & 11 & 0,31 & 1,68 & 5,78 & 4,13 & $<50$ \\
\hline MPH3 & $40-80$ & 1,28 & 25 & 68 & 7 & 0,22 & 0 & 5,74 & 4,39 & $<50$ \\
\hline GaPH1 & $0-2$ & na & 35 & 42 & 23 & 4,71 & 10,62 & 4,11 & 3,30 & $<50$ \\
\hline $\mathrm{GaPH} 2$ & $2-10$ & 0,66 & 29 & 70 & 1 & 3,99 & 4,33 & 5,04 & 4,15 & $<50$ \\
\hline GaPH3 & $10-33$ & 0,77 & 35 & 62 & 3 & 1,74 & 2,76 & 5,17 & 4,25 & $<50$ \\
\hline $\mathrm{GaPH} 4$ & $33-44$ & na & 38 & 56 & 6 & 0,95 & 0 & 5,21 & 4,10 & $<50$ \\
\hline GaPH5 & 44-58 & na & 38 & 49 & 13 & 0,72 & 1,30 & 5,11 & 4,01 & $<50$ \\
\hline GaPH6 & $58-70$ & 0,91 & 43 & 45 & 12 & 0,40 & 0 & 5,15 & 4,03 & $<50$ \\
\hline GaPH7 & $70-90$ & na & 56 & 33 & 12 & 0,24 & 0 & 5,20 & 4,01 & $<50$ \\
\hline BaPH1 & $0-7$ & 0,87 & 35 & 47 & 17 & 9,46 & 109,8 & 5,57 & 5,21 & 43,0 \\
\hline $\mathrm{BaPH} 2$ & $7-25$ & 0,92 & 64 & 35 & 1 & 5,78 & 103,9 & 5,20 & 4,72 & 50,8 \\
\hline BaPH3 & $25-50$ & 0,98 & 14 & 51 & 35 & 2,79 & na & 5,61 & 4,84 & 65,1 \\
\hline TiPH1 & $0-15$ & 0,88 & 15 & 50 & 36 & 4,64 & 47,6 & 6,67 & 5,78 & 51,9 \\
\hline TiPH2 & $15-35$ & 0,87 & 17 & 50 & 33 & 1,74 & 2,7 & 7,41 & 5,81 & 59,6 \\
\hline ТiPH3 & $35-70$ & 0,90 & 75 & 11 & 14 & 1,56 & na & 7,75 & 6,09 & 65,3 \\
\hline
\end{tabular}

Megjegyzés: A talajszelvények kódjai: lásd 1. táblázat. (2) $\rho$ : térfogattömeg; (6) OC: szerves-szén \%; (7) P: felvehető foszfortartalom; (8) B: bázistelítettség; na = nincs adat

valószínűséggel a mikroszkópos vizsgálatok során megfigyelt vasasan impregnált és erősen mállott vulkáni kőzetdarabokból, illetve a sötétvörös vaskiválásokból származik.

Hasonlóan magas értékeket kaptunk a tihanyi $(2,08-2,28 \%)$ és a badacsonyi $(1,27-1,78 \%)$ szelvények esetében is. A standard peroxidos és sósavas előkezelés gyakorlatilag érintetlenül hagyja a szeszkvioxidok által cementált pszeudohomok szemcséket (PEDE \& LANGOHR, 1983). Idős, kristályos vasoxidok jelenlétére utalnak a tanulmányozott szelvények többségében az $\mathrm{Fe}_{\mathrm{o}} / \mathrm{Fe}_{\mathrm{d}}$ arány alapján meghatározott alacsony aktivitási értékek (MIzOTA \& VAN REEUWIJK, 1989). Ez szintén magyarázat lehet a diszpergálásnak ellenálló szerkezetre. Galyatető esetében a diszpergálási gondok az amorfkolloidok jelenlétével is jól magyarázhatók. Vékony- 


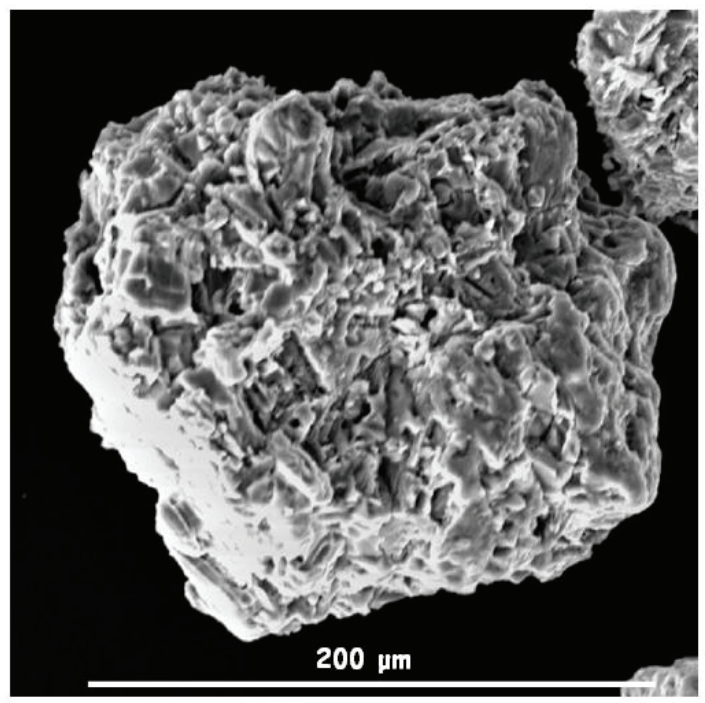

2. ábra

Pszeudohomok-szemcse (Galyatető, 33-44 cm)

csiszolatokban a talajalapanyag 0-33 cm mélységig izotróp (STOOPS, 2003), mely tulajdonság a talajalapanyag differenciálatlanságát jelenti, ahol a kolloid fázis amorf. Az igen alacsony $\mathrm{Si}_{\mathrm{o}}$-tartalmat tekintve (5. táblázat) az amorfkolloidok nagy valószínüséggel szerves-fém komplexek.

A ditionitos extrakciós értékekből az amorf és kristályos szeszkviokszidok mennyiségére lehet következtetni. Az ammónium-oxalátos kivonással nyert oldatokból három komponenst becsülünk: az „amorf”, illetve a szerves fázishoz kötött alumíniumot és vasat, továbbá az amorf alumíniumszilikátok mennyiségét. Ebből adódóan sok esetben az oxalát-oldható alumínium $\left(\mathrm{Al}_{\mathrm{o}}\right)$ mennyisége meghaladja a ditionit-oldható $\left(\mathrm{Al}_{\mathrm{d}}\right)$ alumíniumét. A pirofoszfátos extrakció értékeiből a szerves fázishoz kötött szerves-fém komplexeket becsülhetjük (BLAKEMORE et al., 1987). A galyatetői szelvény esetében a pirofoszfát-oldható alumínium $\left(\mathrm{Al}_{\mathrm{p}}\right)$ értékek jóval meghaladják az oxalát-oldhatókét $\left(\mathrm{Al}_{\mathrm{o}}\right)$. MIZOTA és VAN REEUWIJK (1989) szerint a nátrium-pirofoszfátos oldás során nemcsak a szerves fázishoz kötött fémek, hanem a lúgos oldás következtében a szervetlen komponensekben (alumínium-hidroxidok, gibbsit) található alumínium is az oldatba kerül. Így az értelmezéseknél a pirofoszfátos adatok eredményeit célszerübb a hidroxi-Al fázis indikálására alkalmazni, mely jó összefüggést mutat a foszfátmegkötés során kapott értékekkel (5. táblázat).

Azokban a talajokban, ahol a polivalens ionkoncentráció alacsony, következésképpen a vizes oldatban mért pH 4,5-6,5 között van és vízháztartásuk kilúgzó (VAN RANST, 1991) lehetséges az agyagvándorlás (4. táblázat), melyet jól igazolnak a terepen észlelt agyaghártyák (2. táblázat), illetve a vékonycsiszolatokból leírtak. 
5. táblázat

A vizsgált minták foszfátmegkötése $\left(\mathrm{P}_{\text {ret }}\right)$, valamint $\mathrm{Al}$, Fe és Si elemösszetétele

\begin{tabular}{|c|c|c|c|c|c|c|c|c|c|c|}
\hline \multirow{2}{*}{\multicolumn{2}{|c|}{$\begin{array}{c}(1) \\
\text { Minta }\end{array}$}} & \multirow[t]{2}{*}{$\begin{array}{l}(2) \\
P_{\text {ret }}\end{array}$} & \multicolumn{2}{|c|}{$\begin{array}{l}\text { (3) } \\
\text { Nátrium-piro- } \\
\text { foszfát-oldható }\end{array}$} & \multicolumn{2}{|c|}{$\begin{array}{l}\text { (4) } \\
\text { Nátrium-di- } \\
\text { tionit-oldható }\end{array}$} & \multicolumn{3}{|c|}{$\begin{array}{c}\text { (5) } \\
\text { Ammónium-oxalát } \\
\text { oldható }\end{array}$} & \multirow{3}{*}{$\mathrm{Fe}_{\mathrm{o}} / \mathrm{Fe}_{\mathrm{d}}$} \\
\hline & & & $\mathrm{Al}_{\mathrm{p}}$ & $\mathrm{Fe}_{\mathrm{p}}$ & $\mathrm{Al}_{\mathrm{d}}$ & $\mathrm{Fe}_{\mathrm{d}}$ & $\mathrm{Si}_{\mathrm{o}}$ & $\mathrm{Al}_{\mathrm{o}}$ & $\mathrm{Fe}_{0}$ & \\
\hline kód & $\mathrm{cm}$ & \multicolumn{8}{|c|}{$\%$} & \\
\hline APH1 & $0-5$ & 17 & 0,06 & 0,05 & 0,10 & 0,85 & 0,04 & 0,11 & 0,11 & 0,13 \\
\hline APH2 & $5-25$ & 12 & 0,01 & 0,008 & 0,04 & 0,31 & 0,02 & 0,06 & 0,02 & 0,06 \\
\hline APH3 & $25-44$ & 12 & 0,01 & 0,006 & 0,02 & 0,14 & 0,01 & 0,03 & 0 & 0 \\
\hline EPH1 & $0-12$ & 12 & 0,16 & 0,09 & 0,08 & 0,48 & 0,02 & 0,081 & 0,075 & 0,16 \\
\hline ЕРH2 & $12-25$ & 23 & 0,67 & 0,31 & 0,07 & 0,49 & 0,03 & 0,086 & 0,033 & 0,07 \\
\hline EPH3 & $25-55$ & 12 & 0,30 & 0,15 & 0,06 & 0,42 & 0,03 & 0,078 & 0,029 & 0,07 \\
\hline TPH1 & $0-12$ & 21 & 0,10 & 0,18 & 0,17 & 0,92 & 0 & 0,23 & 0,21 & 0,23 \\
\hline ТPH2 & $12-45$ & 26 & 0,07 & 0,65 & 0,16 & 1,06 & 0 & 0,21 & 0,29 & 0,27 \\
\hline ТPH3 & $45-60$ & 15 & 0,04 & 0,40 & 0,12 & 0,93 & 0 & 0,17 & 0,19 & 0,20 \\
\hline MPH1 & $2-20$ & 23 & 0,15 & 0,20 & 0,21 & 1,70 & 0,03 & 0,22 & 0,42 & 0,25 \\
\hline МРH2 & $20-40$ & 30 & 0,15 & 0,16 & 0,16 & 1,90 & 0,04 & 0,21 & 0,45 & 0,24 \\
\hline MPH3 & $40-80$ & 38 & 0,21 & 0,12 & 0,18 & 1,95 & 0,07 & 0,27 & 0,52 & 0,27 \\
\hline GaPH1 & $0-2$ & 61 & 0,59 & 0,50 & 0,60 & 3,17 & 0,04 & 0,43 & 0,78 & 0,25 \\
\hline $\mathrm{GaPH} 2$ & $2-10$ & 39 & 0,41 & 0,39 & 0,44 & 3,95 & 0,04 & 0,38 & 0,79 & 0,20 \\
\hline GaPH3 & $10-33$ & 38 & 0,35 & 0,34 & 0,43 & 3,90 & 0,04 & 0,37 & 0,76 & 0,19 \\
\hline GaPH4 & $33-44$ & 47 & 0,27 & 0,28 & 0,37 & 3,97 & 0,05 & 0,36 & 0,68 & 0,17 \\
\hline GaPH5 & $44-58$ & 40 & 0,24 & 0,21 & 0,39 & 4,05 & 0,05 & 0,35 & 0,75 & 0,19 \\
\hline GaPH6 & $58-70$ & 30 & 0,21 & 0,20 & 0,32 & 3,78 & 0,05 & 0,29 & 0,62 & 0,16 \\
\hline GaPH7 & 70-90 & 30 & 0,10 & 0,07 & 0,30 & 3,97 & 0,04 & 0,22 & 0,49 & 0,12 \\
\hline BaPH1 & $0-7$ & 23 & 0,11 & 0,29 & 0,21 & 1,27 & 0,05 & 0,32 & 0,58 & 0,46 \\
\hline $\mathrm{BaPH} 2$ & $7-25$ & 29 & 0,15 & 0,49 & 0,24 & 1,45 & 0,05 & 0,34 & 0,73 & 0,50 \\
\hline BaPH3 & $25-50$ & 28 & 0,10 & 0,49 & 0,24 & 1,78 & 0,06 & 0,36 & 0,88 & 0,49 \\
\hline TiPH1 & $0-15$ & 30 & 0,06 & 0,17 & 0,23 & 2,08 & 0,10 & 0,35 & 0,49 & 0,24 \\
\hline TiPH2 & $15-35$ & 36 & 0,05 & 0,06 & 0,23 & 2,28 & 0,13 & 0,40 & 0,50 & 0,22 \\
\hline ТiPH3 & $35-70$ & 34 & 0,04 & 0,06 & 0,21 & 2,13 & 0,15 & 0,42 & 0,51 & 0,24 \\
\hline
\end{tabular}

Ugyanakkor, Magas-Tax esetében, a laboratóriumban végzett mechanikai szemcseösszetétel meghatározás nem igazolta az agyagvándorlást. Így a talajosztályozás felé a kérdés az, hogy mit részesítünk előnyben a morfológiai megfigyeléseket vagy a laboratóriumi méréseket.

\section{Talajosztályozás}

A vulkáni kőzeten kialakult talajok hazánk genetikai és talajföldrajzi osztályozási rendszerében a kőzethatású fötípusban fekete nyirokként és rankerekként, illetve a barna erdőtalajok (BET) között agyagbemosódásos BET, barnaföldekként vagy Ramann-féle BET, illetve savanyú nem podzolos BET fordulhatnak elö 
(STEFANOVITS, 1971; StefanOvits et al., 1999). Mindkét főtípusnál az éghajlati viszonyok meghatározóak a talajképződésben. Az osztályozási egységek lehatárolásának alapja a talaj morfológiai bélyegei alapján megállapított folyamattársulások (STEFANOVITS et al., 1999). A diagnosztikai szemléleten alapuló osztályozási rend-

\begin{tabular}{|c|c|c|c|c|c|c|}
\hline 1. lépés: & \multicolumn{5}{|c|}{$\begin{array}{l}\text { Tihanyi szelvény TiPH1 szintjének adatainak } \\
\text { diagnosztizálása mollic szint kritériumai alapján }\end{array}$} & \multirow{5}{*}{$\begin{array}{l}\text { TiPH1 szint } \\
\text { vastagsága } \\
\text { mollic szint } \\
\text { diagnosztizálásához } \\
\text { túl sakély }\end{array}$} \\
\hline \begin{tabular}{l|l} 
Minta & cm \\
\end{tabular} & Szerkezet & Munsell sxín & $\mathrm{OC} \%$ & B\% & Lcm & \\
\hline \begin{tabular}{|l|l|} 
TiPH1 & $0-15$ \\
\end{tabular} & SZ+Rö & 10YR 2/1 & 4,64 & 51,9 & 15 & \\
\hline TiPH2 15-35 & SZ+Rö & 10 YR $2 / 2$ & 1,74 & 59,6 & 20 & \\
\hline TiPH3 35-70 & $\mathbf{S Z + R a ̈ ~}$ & $10 \mathrm{YR} 3 / 1$ & 1,56 & 65,3 & 35 & \\
\hline 2. lépés: & \multicolumn{5}{|c|}{$\begin{array}{l}\text { Tihanyi szelvény TiPH2 szintjének adatainak } \\
\text { diagnosztizálása mollic szint kritériumai alapján }\end{array}$} & \multirow{4}{*}{$\begin{array}{l}\text { TiPH1 +TiPH2= } \\
\text { mollic szint }\end{array}$} \\
\hline \begin{tabular}{l|l} 
Minta & cm \\
\end{tabular} & Szerkezet & Munsell sxin & $O C \%$ & $\mathbf{B} \%$ & $\Sigma \mathrm{cm}$ & \\
\hline \begin{tabular}{l|l} 
TiPH1 & $0-15$ \\
TiPH2 & $15-35$
\end{tabular} & $\frac{\mathbf{S Z}+\mathbf{R} \ddot{\mathbf{B}}}{\mathbf{S Z}+\mathbf{R} \ddot{\mathbf{0}}}$ & \begin{tabular}{|l|}
$10 \mathrm{YR} 2 / 1$ \\
$10 \mathrm{YR} 2 / 2$
\end{tabular} & $\begin{array}{l}4,64 \\
1,74\end{array}$ & \begin{tabular}{|l|}
51,9 \\
59,6
\end{tabular} & \begin{tabular}{|l|}
15 \\
20 \\
\end{tabular} & \\
\hline TiPH3 35-70 & SZ+Rö & $10 \mathrm{YR} \mathrm{3/1}$ & 1,56 & 65,3 & 35 & \\
\hline 3. lépés: & \multicolumn{5}{|c|}{$\begin{array}{l}\text { Tihanyi szelvény TiPH3 szintjének adatainak } \\
\text { diagnosztizálása mollic szint kritériumai alapján }\end{array}$} & \multirow{5}{*}{$\begin{array}{l}\text { TiPH1 +TiPH2+ } \\
\text { TiPH3= } \\
\text { mollic szint }\end{array}$} \\
\hline \begin{tabular}{l|l} 
Minta & cm \\
\end{tabular} & \begin{tabular}{|l|} 
Szerkezet \\
\end{tabular} & Munsell sxín & $\mathrm{OC} \%$ & B\% & $\Sigma \mathrm{cm}$ & \\
\hline \begin{tabular}{|l|l|} 
TiPH1 & $0-15$ \\
\end{tabular} & $\mathbf{S Z + R \ddot { ~ }}$ & 10YR $2 / 1$ & 4,64 & 51,9 & 15 & \\
\hline TiPH2 15-35 & SZ+Rö & 10 YR $2 / 2$ & 1,74 & 59,6 & 20 & \\
\hline TiPH3 35-70 & SZ+Rä & $10 \mathrm{YR} 3 / 1$ & 1,56 & 65,3 & 35 & \\
\hline
\end{tabular}

3. ábra

Diagnosztikai osztályozás gyakorlati menete

szerek szintén terepi megfigyeléseken alapulnak, és ezeket egészítik ki és igazolják a laboratóriumi vizsgálatok számszerủ adatai. Maga az osztályozás gyakorlati menete ritkán kerül a publikációkba (3. ábra), ugyanakkor a problémás mérési adatok, illetve hiányzó adatok esetében hasznosnak érezzük bemutatni, hogy ez miképpen hidalható át.

A diagnosztikai szintek lehatárolása egyrészt a genetikai szintek terepen leírt tulajdonságain, másrészt a mintavételi szintek laboratóriumban mért adatain alapul. Guy D. Smith íratlan szabálya szerint az osztályozást célszerü mindig a mollic szint diagnosztizálásával kezdeni (Langohr szóbeli közlése). A jobb áttekinthetőség kedveért az adatokat érdemes táblázatosan elrendezni. A táblázat oszlopaiban a diagnosztizáláshoz kért paraméterek találhatók (3. ábra esetében mollic szinté), míg a sorokban a vizsgált szelvények mintavételi szintjeinek adatai.

Abban az esetben, amikor a lekérdezett tulajdonság egyezik a diagnosztizálásban kérdezettekkel, akkor a vizsgált adatot egy választott szín segítségével jelöltük. Sok esetben egy-egy mintavételi szint vastagsága nem elégséges a diagnosztizálásához, ekkor az alatta levő szint adatait vizsgáljuk, és amennyiben az a kérdezett 
kritériumokkal egyezik, akkor két vagy több mintavételi szint összevonásából lesz egy diagnosztikai szint. Így lehetséges például az, hogy a tihanyi szelvény teljes egészében mollic szint. Ez a továbbiakban már kizárja az altalaj-szintek további diagnosztizálását. Amennyiben egy adat hiányzik, vagy az osztályozástól eltérő módszerrel lett meghatározva, avagy a mérés megbízhatósága kérdéses, abban az esetben egy halványabb színnel vagy egy kérdőjellel érdemes kijelölni a vizsgált paramétert.

A galyatetői szelvény esetében hiányoztak a bázistelítettség adatok, melynek megléte nélkül nem különíthető el a mollic diagnosztikai szinttől az umbric. Ebben a konkrét esetben a probléma megoldható volt, hiszen a galyatetői szelvény mintáinak (5. táblázat) vizes pH-ja 4,11 és 5,21 között volt. Irodalmi adatok alapján, gyakorlatilag $95 \%$ feletti biztonsággal állíthatjuk, hogy a feltalaj bázistelítettsége ebben az esetben $50 \%$ alatti.

A munkafájlokban a problémás helyek rögzítve vannak, így a későbbiekben a lehetőségekhez mérten vissza lehet térni az adatok pótlására vagy a mérések megismétlésére. Így a galyatetői szelvény feltalajának $58 \mathrm{~cm}$-e mind szerkezetében, színében, szerves-szén-tartalmában, vastagságában teljesíti az umbric szint kritériumait.

Badacsony esetében a $7 \mathrm{~cm}$ vastagságú BaH1-szint bázistelítettsége csak 43\%, ugyanakkor az alsóbb szintek összes paramétere a mollic szint diagnosztikai kritériumait teljesíti. Ilyen esetekben, az összes érintett mintavételi szint matematikai átlagát érdemes alapként venni és ez alapján a szelvényben a bázistelítettség meghaladja az 50\%-ot, tehát a badacsonyi szelvény mollic diagnosztikai szinttel rendelkezik. Az osztályozás során az összes lehetséges diagnosztikai szintet, tulajdonságot és anyagokat áttekintettük. A 6. táblázat a diagnosztikai paraméterek alapján meghatározott referencia talajcsoportokat, illetve a hozzájuk tartozó diagnosztikai jelzőket mutatja be. A jelzők kitételénél nem a táblázatosan közölt prioritási listákat alkalmaztuk, hanem abc-sorrendben végighaladtunk a WRB (1998) kötet végén található jelzőkön, és az összes érvényest a vizsgált talaj névéhez illesztettük.

\section{6. táblázat}

A vizsgált talajszelvények besorolása a genetikai talajosztályozás és a World Reference Base for Soil Resources (WRB, 1998) szerint

\begin{tabular}{|c|c|c|c|}
\hline $\begin{array}{l}\text { (1) } \\
\text { Talajszelvény } \\
\text { helye }\end{array}$ & $\begin{array}{c}\text { (2) } \\
\text { Genetikai típus }\end{array}$ & \multicolumn{2}{|c|}{$\begin{array}{l}\text { Referencia talajcsoport és } \\
\text { jelzők (WRB, 1998) }\end{array}$} \\
\hline Andornaktálya & a) Fekete nyirok & Cambisol & eutric, ochric \\
\hline Tolcsva & a) Fekete nyirok & Luvisol & eutric,ochric \\
\hline Tokaj & b) Barnaföld & Phaeozems & (thapto-)cambic, skeletic \\
\hline Magas-Tax & b) Barnaföld & Cambisol & dystric, ochric \\
\hline Galyatető & $\begin{array}{l}\text { c) Agyagbemosódásos } \\
\text { barna erdőtalaj (ABET) }\end{array}$ & Luvisol & cutanic, umbrihumic, \\
\hline Badacsony & a) Fekete nyirok & Phaeozem & eutric, hortic, endoleptic, \\
\hline Tihany & a) Fekete nyirok & Phaeozem & eutric, pachic \\
\hline
\end{tabular}




\section{Diagnosztikai jellemzők és talajképzödési folyamatok}

A badacsonyi, tihanyi és tokaji szelvények esetében a humuszos feltalajt mollicként diagnosztizáltuk. A tokaji szelvény esetében, a kőzet-felhalmozódási szint alatt, az eltemetett $2 \mathrm{~B}+\mathrm{D}$-szint thapto-cambic bélyegeket visel (6. táblázat). $\mathrm{Az}$ említett három szelvényt diagnosztikai bélyegeik alapján Phaeozem-ként soroltuk be (WRB, 1998). Jellemző rájuk az erős humuszosodás, kilúgzás, terepi megfigyelések alapján az agyagosodás. Mindhárom szelvénynél a történelmi adatok és a földhasználat-változás elemzése során feltételeztük az erős emberi hatást. A badacsonyi szelvénynél a kémiai tulajdonságok és a földhasználat múltjának ismerete egyértelmúen igazolja az emberi hatást. Így ezt a névben a hortic jelző használatával jeleztük. A másik két szelvénynél az emberi hatás - bolygatás - bélyegek nem egyértelmüek, ezek további részletes feltárást igényelnek.

$\mathrm{Az}$ andornaktályi és tolcsvai szelvények humuszos feltalajuk sekélysége miatt csak ochric diagnosztikus szinttel rendelkeznek. Elmondható az is, hogy relatív sekélységük ellenére rendelkeznek (színben, szerkezetben és agyagosságban a humuszos A-szinttől eltérö) B-szinttel. A szelvénysekélység az ignimbritek nagyfokú mállás-ellenállóságával hozható összefüggésbe (SzÉKELY, 1997). Tolcsva esetében a szelvényfejlődés lényegesen előrehaladottabb, EPH2 mintavételi szintje teljesíti az argic-szint diagnosztizáláshoz szükséges feltételeket. Ez nagy valószínüséggel a szelvény hegylábi földrajzi elhelyezkedésével magyarázható, melynek köszönhetően több csapadék jut be a talajba a vegetáció nélküli nedves periódusban. Így a mállás és kilúgzás is előrehaladottabb, mint Andornaktályán, következésképpen az agyagosodás is intenzívebb. Az andornaktályi szelvény APH2-szintje cambic-ként lett diagnosztizálva. Az $50 \mathrm{~cm}$-en belül megtalálható összefüggő alapkőzet leptic jelzővel rendelkezik. Jelen esetben ez a névből elhagyható, hiszen a terepen mért effektív gyökérmélység (szőlő) minden esetben meghaladta az 1,5 m-t (6. táblázat).

A magas-tax-i és a galyatetői szelvények csapadék-utánpótlása az év nagy részében szinte állandó lefelé irányuló vízmozgást eredményez. Ezek a talajok anyagforgalmukat tekintve az erôs kilúgzás típusába tartoznak (VÁRALLYAY, 1985). A magas-tax-i szelvény feltalaját ochric szintként diagnosztizáltuk, az erős kilúgzás következtében fellépő alacsony bázistelítettségre a dystric jelző utal (6. táblázat). Az altalaj mintavételi szintjeinek laboratóriumban mért agyagtartalma szerint nincs szintek közötti textúrdifferenciálódás, viszont ugyanezekben a szintekben, a terepi vizsgálatok során, jól észlelhető agyaghártyákat írtunk le. Az altalaj - szerkezetének fejlettsége alapján - cambic szint. Az agyaghártyák jelölésére szolgáló cutanic jelzőt csak Luvisol-oknál használhatjuk, így Magas-Tax esetében ezt el kellett hagyni.

Galyatető magasabb fekvése, hüvösebb éghajlata és hosszabb hó-akkumulációs időszaka nagyobb arányú szervesanyag-felhalmozódásnak kedvez Magas-Taxhoz képest. A nyári időszakban a talajlakó állatok talajkeverésének köszönhetően egy vastagabb humuszos szint alakult ki, mely teljesíti az umbric-szint diagnosztikai követelményeit. A börzsönyi szelvényhez képest a galyatetői szelvény fekvését „talajnedvesség gyüjtö”-ként jellemeztük: több hóval borított nap, mini-lapály és középső lejtőszakasz. Mindez intenzív mállást, kilúgzást és agyagvándorlást eredményez. A GaPH5- és GaPH6-szintekből vett vékonycsiszolatokban megfigyelt 
agyaghártyák jellegüket tekintve „porosak”, mely a kolloidfrakció alumínium által flokkulált állapotára utal. A flokkulált részecskéket a hóolvadás során lefele szivárgó olvadékvíz mozdítja el. Ezt a folyamatot VAN VLIET-LANOË (1985) belső eróziónak vagy kolluviációnak nevezi, mely folyamat végeredményben szintek közötti textúrdifferenciálódáshoz vezet. Az említett szintek laboratóriumban mért adatai az argic-szint diagnosztizálásához szükséges öt paraméter mindegyikét teljesítik (WRB, 1998).

A galyatetői szelvény genetikai eredetét tekintve $33 \mathrm{~cm}$-től régebbi geológiai kor talajképződésének eredménye. A szelvény „közepén” található kőzettörmelékfeldúsulás, 33-44 cm mélységben, periglaciális felszínpusztulást indikáló bélyeg. SzÉKELY (1997) szerint a hideg beköszöntével a kezdeti erős kifagyás után a hegytetők saját törmelékükbe burkolóztak. Amennyiben feltételezzük a negyedidőszak elötti, szubtrópusi klíma alatti, intenzív talajdifferenciálódást, akkor nagy valószínüséggel a jégkorszakok folyamán a fagy a talajtakarót érintette elöször. A felmelegedés a lejtős területeken geliszoliflukciót eredményezett (STEFANOVITS, 1973). A felolvadt részekből gyakorlatilag a könnyebb részecskék (talaj) „kifolytak”, míg helyben a mállásnak ellenálló nehezebb kőzetek maradtak. Több ilyen fagyásolvadási ciklus következtében egy relatív közettörmelék-feldúsulás következhetett be a régebbi korok talajainak felszínén. Ezt később a kőzetek fagyaprózódása során keletkezett finom por, illetve a közeli folyók medréből kifújt kőzetliszt fedhette be. A periglaciális hatások annál erősebben érvényesültek minél magasabb volt a hegység és minél mállékonyabb a kőzet. Ezek a feltételek leginkább a Mátrára és a Börzsönyre voltak jellemzőek (SzÉKELY, 1997). A galyatetői szelvény vékonycsiszolataiban a kvarcszemcsék eloszlása alapján jól nyomon követhető a löszhatás, mely kb. $55 \mathrm{~cm}$ mélységig (3. táblázat) mutatható ki a szelvényben. Ezeken, a frissen lerakódott és fagyaprózódásból keletkezett üledéken, az interstadiálisokban megindulhatott egy újabb talajképződési ciklus. A vékonycsiszolatokban megfigyelt izotróp kolloidszövet - WADA és AOMINE (1977) adatai alapján - kb. 20000 év elteltével alakul át 1:1 kristályrácsú agyagásvánnyá. Következésképpen a galyatetői szelvény 0-33 cm mélységig terjedő talajszintje 20000 évnél fiatalabb, tehát posztglaciális talajképződmény.

\section{Összefoglalás}

Az európai vulkáni rendszerek talajerőforrásait feltérképező COST 622 projekt keretében vizsgáltuk a belső-kárpáti vulkáni vonulat hazánk területére eső, vulkáni kőzeteken képződött talajait. A vulkáni kőzetet létrehozó vulkánosság jellege alapján (mészalkáli: savanyú és intermedier, illetve alkálibazalt vulkánosság) hét mintaterületet jelöltünk ki. A vizsgált talajok genetikai szintjein részletes makro- és mikromorfológiai, kémiai és fizikai vizsgálatokat végeztünk. Vizsgálataink célja a diagnosztikai bélyegek (WRB, 1998) és a részletes morfológiai megfigyelések öszszehasonlítása volt. Diagnosztikai tulajdonságok alapján a legváltozatosabb talajnak a fekete nyirok bizonyult, mely a mintaterületek talajnedvesség-forgalmi és mikroklimatikus különbségei alapján Phaeozem-ként (Badacsony, Tihany), Cambisol- 
ként (Andornaktálya) és Luvisol-ként (Tolcsva) került besorolásra. Valamennyi vizsgált mintaterületen morfológiai és kémiai tulajdonságok alapján aktív és inaktív folyamatokra utaló bélyegeket diagnosztizáltunk. A múltban végbement folyamatokra utalnak a geliszolflukciós transzport bélyegei és az igen erős fagyhatásra képződött pszeudohomok-szemcsék. Aktív folyamatoknak tekinthető: a humuszosodás, intenzív mállás és agyagosodás, kilúgzás és az agyagvándorlás. Galyatető esetében a periglaciális fagyaprózódásból keletkezett finom por intenzív kémiai mállását, amorfkolloid képződését sikerült detektálni.

Kulcsszavak: vulkáni kőzet, talajképződés, talaj mikromorfológiai, diagnosztikai bélyegek

\section{Irodalom}

Blakemore, L. C., Searle, P. L. \& Daly, B. K., 1987. Methods for Chemical Analysis of Soils. New Zealand Soil Bureau Scientific Report 80. Lower Hutt.

BuZÁs I. (szerk.), 1988. Talaj- és agrokémiai vizsgálati módszerkönyv 2. Mezőgazdasági Kiadó. Budapest.

BUZÁs I. (szerk.), 1993. Talaj- és agrokémiai vizsgálati módszerkönyv 1. INDA 4231 Kiadó. Budapest.

Duchaufour, P., 1982. Pedology: Pedogenesis and Classification. Allen \& Unwin. London.

FAO, 1990. Guidelines for Soil Description. FAO-ISRIC. $3^{\text {rd }}$ (revised) ed. Rome.

FEHÉR, O. \& MADARÁSZ, B., 2004. Historical land use change on volcanic soils in Hungary. In: Proc. $4^{\text {th }}$ International Congress of the ESSC. Budapest. 200-202.

FEKETE L., 1891. Erdészeti talajtan. Selmecbánya.

HARANGI Sz., 1999. A medencebelseji alkálibazalt-vulkánosság. In: Pannon Encyclopaedia. (Szerk.: KARÁTSON, D.) CD-Rom. Kertek 2000. Budapest.

Mizota, C. \& VAN REEUWIJK, L. P., 1989. Clay mineralogy and chemistry of soils formed in volcanic material in diverse climatic regions. Soil Monograph 2. ISRIC. Wageningen.

NAGYMAROSY A., 2004. A termőhely vonzásában. In: Terra Benedicta (Szerk.: RoHÁLY G.) 10-23. Akó Kiadó. Budapest.

PEDE, K. \& LANGOHR, R., 1983. Microscopic study of pseudo-particles in dispersed soil samples. In: Soil Micromorphology. Proc. VI. International Working Meeting on Soil Micromorphology. (Eds.: Bullock, P. \& Murphy, C. P.) 265-271. A. B. Academic Press. London.

RÓZSAVÖLGYI J. \& STEFANOVITS P., 1960. Barna erdőtalajok vékonycsiszolatainak vizsgálata. Agrokémia és Talajtan. 9. 365-380.

SteFAnOVITS P., 1951. Andezittufán kialakult talajok a Börzsöny-hegységben. Agrokémia és Talajtan. 1. 309-320.

StefAnOVITS P., 1956. Magyarország talajai. Akadémiai Kiadó. Budapest.

StefanOvits, P., 1971. Brown Forest Soils of Hungary. Akadémia Kiadó. Budapest.

Stefanovits, P., 1973. The influence of the Pleistocene slope deposit formation and mass movement on the soil cover. Földrajzi Közlöny. 21. (2) 145-151. 
Stefanovits P., FileP Gy. \& FÜleKy Gy., 1999. Talajtan. Mezőgazda Kiadó. Budapest.

Stoops, G., 2003. Guidelines for Analysis and Description of Soil and Regolith Thin Sections. Soil Science Society of America, Inc. Madison.

SzABÓ J. \& MolnÁR J., 1867. Tokaj-Hegyalja talaja. Pest.

SZAKÁCS S. \& KARÁTSON D.,1999. A belső-kárpáti mészalkáli vulkánosság. In: Pannon Encyclopaedia. (Szerk.: KARÁTSON D. CD-rom. Kertek 2000. Budapest.

SzÉKELY A.,1997. Vulkánmorfológia. ELTE Eötvös Kiadó. Budapest.

SzENDREI G., 2001. A hazai talajtípusok mikromorfológiája. Budapest.

TREITZ P., 1905. A Nagysomlyó-hegy szőlőterületének talajismereti leírása. Budapest.

VAN RANST, E., 1991. Soil Genesis. Concepts of Soil Development. Formation of Diagnostic Horizons and Materials. Lecture Notes. ITC. Gent.

VAN VLIET LANOË, B., 1985. Frost effects in soils. In: Soils and Quaternary Landscape Evolution. (Ed.: BoARDMAN, J.) 117-158. John Wiley \& Sons, Ltd. New York.

VÁRALLYAY GY., 1985. Magyarország talajainak vízháztartási és anyagforgalmi típusai. Agrokémia és Talajtan. 34. 267-299.

WADA, K. \& AOMINE, S., 1973. Soil development on volcanic materials during the Quaternary. Soil Science. 116. 170-177.

White, R. E., 1997. Principles and Practice of Soil Science. Blackwell Science Ltd. Maldon.

WRB, 1998. World Reference Base for Soil Resources. FAO, ISRIC \& ISSS. Rome.

Érkezett: 2006. február 17. 


\title{
Morphological and Diagnostic Properties of Seven Volcanic Soil Profiles According to the Hungarian Soil Classification and the World Reference Base for Soil Resources (WRB, 1998)
}

\author{
${ }^{1}$ O. FEHÉR, ${ }^{1}$ GY. FÜLEKY, ${ }^{2}$ B. MADARÁSZ and ${ }^{2}$ Á. KERTÉSZ \\ ${ }^{1}$ Szent István University Department of Soil Science and Agrochemistry, Gödöllő \\ ${ }^{2}$ Geographical Research Institute HAS, Budapest (Hungary)
}

\begin{abstract}
Summary
In the framework of the European Cost action entitled Soil Resources of European Volcanic Systems (COST-622) soils formed from volcanic rocks were investigated in detail in selected areas of the Inner-Carpathian volcanic arc in the territory of Hungary. According to the nature of the volcanism (silicic, calc-alkaline or alkaline-basalt) seven representative study sites were chosen, sampled and studied in detail. The objective was to compare how diagnostic features (WRB, 1998) reflect the genetic soil types and properties.

The study of the macro- and micromorphological, physical and chemical properties of soils developed on volcanic rocks allowed several interesting conclusions to be drawn. The "Black Nyirok" genetic soil type showed the highest diversity of diagnostic horizons and properties. This variability was strongly correlated with the soil moisture regimes and microclimatic conditions of the study sites. Black "nyirok" soils with a moderate leaching climate were classified as Phaeozems (Badacsony, Tihany), and those with strong leaching conditions as Cambisols (Andornaktálya) or Luvisols (Tolcsva). Based on morphological and chemical properties it was possible to identify active and inactive soil-forming processes. Soils and loose sediments were affected in the past by the process of gelisolifluction, frost ultra-desiccation and oxido-reduction. Recent acid mull formation is directly influenced by the presence of free iron in the soil system, as well as by the high biological activity of the mesofauna. At present soils in the volcanic regions of Hungary are influenced by leaching and the process of internal colluviation, intense chemical weathering, and freeze and thaw. Amorphous material formation was detected in places affected by frost-shattering.

Table 1. Data on the environment of the study sites. (1) Soil profile code: AP: Andornaktálya, EP: Tolcsva, TP: Tokaj, MP: Magas-Tax, GaP: Galyatető, BaP: Badacsony, TiP: Tihany. (2) Coordinates. (3) Parent material or substrate: A: andesite; I: ignimbrite; B/B*: basalt/pyroclasts. (4) Altitude above sea level, m. (5) Exposure. (6) Slope gradient, \%. (7) Soil temperature regime: mesic. (8) Soil moisture regime type: Udic or Ustic (categories of international classification systems) (9) Vegetation/land use: a) abandond orchard, b) planted forest, c) mountain beech forest, d) planted evergreen forest, e) oak forest. (10) Characteristic species. (11) Grass, \%.

Table 2. Summary of morphological properties of studied soil profiles. (1) Soil profile code. (2) Genetic horizon and depth, $\mathrm{cm}$. (3) Moist colour. (4) Soil texture class: a: clay, av: clay loam, fhv: fine sandy loam, fh+av: fine sand and clay loam. (5) Structure: Bo: fluffy, H: prismatic, M: crumbly, Rö: subangular blocky, SZ: angular blocky. (6) Consistence: L: loose, ET: slightly hard, T: hard. (7) Abundance of rock fragments,
\end{abstract}


\%. (8) Roots: H: fine roots, KÖZ: medium roots, N: very fine roots. (9) Horizon boundary: a) gradual, b) wavy, c) abrupt, d) diffuse. (10) Special features: A: human artifacts (ceramics, bricks, charcoal, etc.), AH: clay coatings, GJ: worm galleries, KK: silica impregnation, KH: stone line, Q: uncoated sand grains, RF/VSZ: redoximorphic mottling. (10) Comments.

Table 3. Summary of micromorphological properties of Galyatetõ soil profile. (1) Microstructure, (2) Shape: m: crumby, rö: subangular blocky, sz: angular blocky; (3) Porosity; (4) Groundmass: Asz: colour of micromass: a) dark brown, b) light brown and brown, c) reddish brown; Akt: aspect of the micromass: d) pigmented, e) heterogenic, f) cloudy; b: b-fabric: I: isotropic, A: anisotropic; V/a: c/f related distribution: P: porphyric; Vw: degree of weathering of coarse fragments; DV: frequency of coarse fragments; Q: frequency of quartz content within the coarse mineral fraction. (5) Pedofeatures: AH: clay coatings, E: excrements, I: loose discontinuous infillings, N: typic disorthic iron nodules.

Table 4. Laboratory analysis of the seven volcanic soil profiles. (1) Soil sample code. (2) Bulk density. (3) Sand content. (4) Silt content. (5) Clay content, \%. (6) Organic carbon content, \%. (7) Available phosphorous content, $\mathrm{mg} / \mathrm{kg}$. (8) Base saturation \%. Remarks: Soil profile codes: See Table 1. na = no data.

Table 5. Phosphate retention and $\mathrm{Al}, \mathrm{Fe}$ and $\mathrm{Si}$ element composition of the examined samples. (1) Soil sample code. (2) Phosphate retention. (3) Sodium pyrophosphateextractable $\mathrm{Al}_{\mathrm{p}}$-aluminium, $\mathrm{Fe}_{\mathrm{p}}$-iron. (4) Sodium dithionite-extractable $\mathrm{Al}_{\mathrm{d}}$-aluminum, $\mathrm{Fe}_{\mathrm{d}^{-}}$iron; (5) Ammonium oxalate-extractable: $\mathrm{Si}_{0}$-silica, $\mathrm{Al}_{0}$-aluminum, $\mathrm{Fe}_{0}$-iron.

Table 6. Classification of the soil profiles according to the genetic concept of the Hungarian classification and WRB (1998). (1) Location of the soil profile. (2) Genetic soil type: a) Black "nyirok", b) Ramann's brown forest soil, c) Brown forest soil with Bt horizon; (3) Reference soil groups and qualifiers.

Fig. 1. Heterogeneity of gelisolifluctional soil fabric. Galyatető, $42-55 \mathrm{~cm}$. AH/ $/$ : clay coating; K: rock fragments; N: typic disorthic nodules of iron; P: void.

Fig. 2. Scanning electron micrograph of pseudosand particle. Galyatetö, $33-44 \mathrm{~cm}$.

Fig. 3. Course of diagnostic classification. 